\title{
Study of Stress on Belt Drive System Integrated with Briquetting Plant
}

\author{
Prashant Agnihotr ${ }^{1}$ and Ajay Kumar Choubey ${ }^{2 *}$ \\ ${ }^{1}$ Lakshmi Narain College of Technology, India \\ ${ }^{2}$ Sagar Institute of Research \& Technology, India
}

Submission: April 14, 2018; Published: June 27, 2018

*Corresponding author: Ajay Kumar Choubey, Assistant Professor, Sagar Institute of Research \& Technology, Bhopal, India, Email: a1ja1y@yahoo.co.in

\begin{abstract}
In briquetting plant, briquettes produces through small pieces of agro residues or by dry material which having moisture contain below $10 \%$. Briquetting plant consists from biomass grinder, screw conveyor and piston-press machine. The piston-press machine operates through open belt drive system. Pulley and belt system is an important part of the briquetting plant, which function is to transfer speed into reciprocating system. In this study, effect of slip and COF on belt life analysis has done through mathematical formulation and numerical simulation. Present study deals pulley simulation has done through help of Finite Element software ANSYS 12.0.1.
\end{abstract}

Keywords: ANSYS; Briquetting plant; COF; Pulley-belt; Slip

\section{Introduction}

We all are well known by the importance of energy and its sources. Energy is the key factor in economic development of every country. The demand of energy is increasing day by day and the supplies of sources are limited. It is globally red alert for fossil fuel like Petrol, Kerosene, Natural Gas, LPG, and Lignite etc. This has made a huge gap between the demand and supply of energy. Renewable energy is the ultimate solution, which can fill this gap.

The briquette is an alternate source of energy. The biomass briquettes are substitute for coal and L.P.G., and research is going on. The Biomass briquettes are made up of renewable source of energy.

The briquetting piston-press is a reciprocating crank type mechanical press with flywheel. The main motor through continuous flat belt drives flywheel. The ground material is feed through a hopper by means of a screw conveyer with its own motor. The vertical screw pre compresses and forces the material downward in to the feeding chamber. From the chamber the materials forced by the ram through a tapered die system on to the cooling track in the form of briquettes. Briquettes formed are cylinder shape. [1]

In this study, we discussing about belt drive-open system of piston-press machine. Belts are used when the distance between the axes of the two shafts to be connected is considerable. A flat belt is a belt with a narrow rectangular cross-section. The flat belts are easier to use and are subjected to minimum bending stress.
In the present paper, the pulley is simulated with ANSYS 12.0.1 Software. This way the concern of different process parameters such as coefficient of friction, power, thickness of belt, slip and tension on belt are studied.

\section{Discussion of various parts}

(Figure 1) Briquetting plant consists from various parts. The main part is as follows:

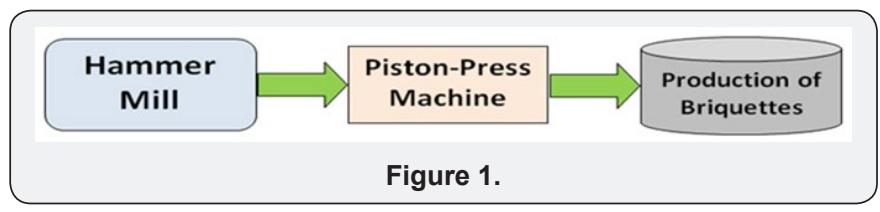

Biomass-grinding machine: It is an important part of the briquetting plant, which function is to convert aggregate material in to small pieces.

Screw conveyor: it is used to carry the raw biomass from storage place to hopper. It is also used to mix the moisture socking agent from the raw biomass.

\section{Piston-press machine:}

a) Hopper: Hopper is use to move the raw material from screw conveyor to processing place. It includes extruder which is used to give a motion to raw biomass only in a one direction. 


\section{Robotics \& Automation Engineering Journal}

b) Ram: Ram is used for forcing the raw biomass in a die holder. Ram is fixed in ram holder. These ram moves in a horizontal direction with the help of motor.

c) Collar: Collar is use to fix the die in a die holder. Also it is used for to prevent the flow of raw biomass in a wrong direction i.e. in motor direction.

d) Die: Die is the part where the briquette get the shape to from the briquette.

Cooling tower: After process of briquette formation it cool at cooling tower and move in a direction of storage place. [2]

In piston-press machine all the rotary as well as reciprocating parts moving through the pulley belt arrangement. Therefore, pulley belt system is very important part of briquetting plant. In this study, discussing about pulley and bet system of briquetting plant (Figure 2).

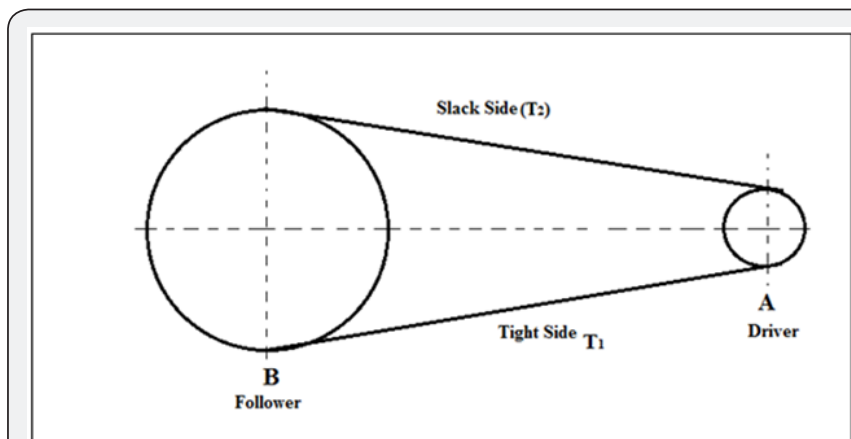

Figure 2: Schematic details of belt drive.

\section{Aim of Study}

The main aim of this study is to investigate:

a) Effects of coefficient of friction (COF)

b) Effect of different Belt thickness ( $t$ ) on the quality of belt

c) Effect of tension (T) on pulley

d) Effect of slip (s).

\section{Methodology}

(Figure 3)

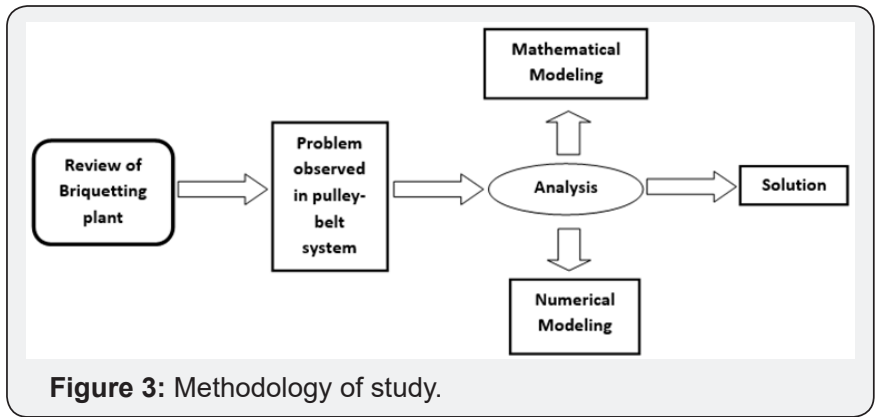

\section{Input Data}

Diameter of Driver $\mathrm{d}_{1}=0.15 \mathrm{~m}$;

Diameter of Follower $\mathrm{d}_{2}=0.85 \mathrm{~m}$;
Speed of Drier $\mathrm{N}_{1}=1475 \mathrm{rpm}$;

Speed of Follower $\mathrm{N}_{2}=$ ?;

Power P=20kW;

\section{Estimation of tension during rotation of driving pulley}

A highly elastic belt is used for belt drive, which is operated by $15 \mathrm{hp}$ electric motor and at the speed of driver \& driven pulleys are $1475 \mathrm{rpm} \& 260 \mathrm{rpm}$, the diameter of driver \& follower pulleys are $150 \mathrm{~mm} \& 850 \mathrm{~mm}$. Center to Center distance is $1.575 \mathrm{~m}$ (Table 1).

Table 1.

\begin{tabular}{|c|c|}
\hline \multirow{2}{*}{ Step } & Value \\
\hline \multirow{2}{*}{ I. V.R. } & $\mathrm{N}_{2}=260 \mathrm{rpm}$ (Without considering thickness) \\
\cline { 2 - 3 } & $\mathrm{N}_{2}=269 \mathrm{rpm}$ (If thickness of belt taken account) \\
\hline II. Slip & $\mathrm{S}=3 \%$ (If thickness of belt taken account) \\
\hline \multirow{2}{*}{\begin{tabular}{c} 
III. \\
\cline { 2 - 2 }
\end{tabular}} & $\mathrm{T}_{1}=3.59 \mathrm{kN}$ (Tension in Tight side at $20 \mathrm{~kW}$ power) \\
\cline { 2 - 2 } & $\mathrm{T}_{2}=1.89 \mathrm{kN}$ (Tension in slack side) \\
\hline
\end{tabular}

Finite element simulation of pulley: Figure 4 showing FE model of pulley model prepared in ANSYS 12.0.1.

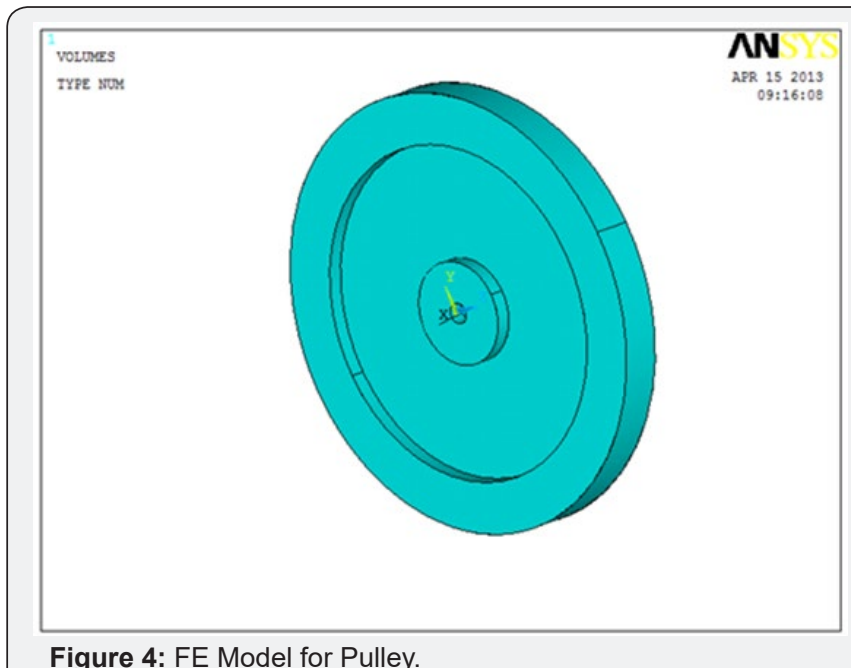

Figure 4: FE Model for Pulley.

The 3-D FE model for pulley was created by using ANSYS 12.0.1 software. The shaft is analyzed in ANSYS in three steps. First is preprocessing which involves modeling, geometric clean up, element property definition and meshing. Next comes, solution which involves imposing boundary conditions and applying loads on the model and then solution runs. Next in sequence comes post processing, which involves analyzing the results plotting different parameters like stress, strain, natural frequency, harmonic frequency and many. The mesh has been generated using tetra free element. The Solid 45 element type is adopted to mesh the model. The mesh of the pulley consists of 83198 elements. 17492 nodes are included in the finite element model. [3-5]. 


\section{Robotics \& Automation Engineering Journal}

\section{Result \& Discussion}

Present study deal with coefficient of friction between belt and pulley and variation of thickness of belt. The stress analysis have done through numerical simulation which shown in Figure 5-7.

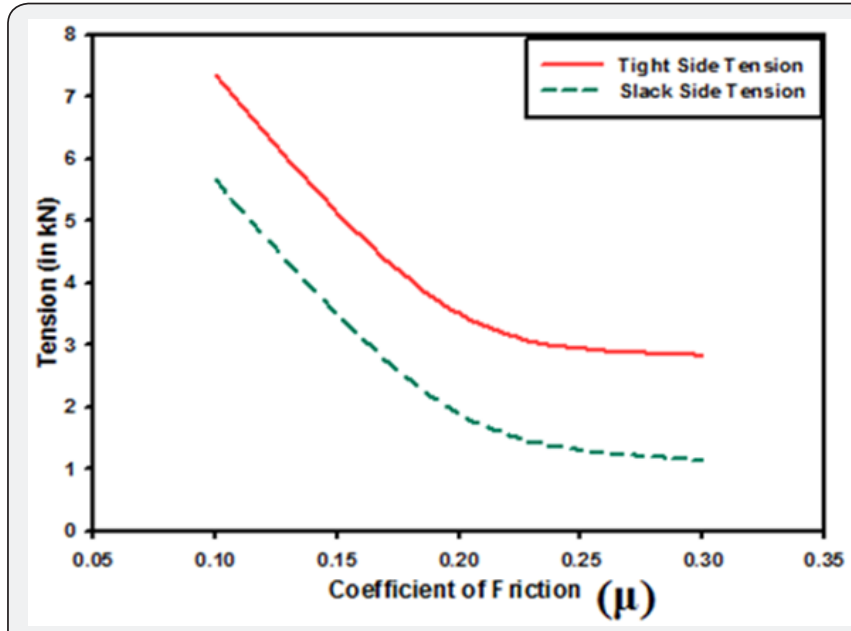

Figure 5: COF vs Tensions.

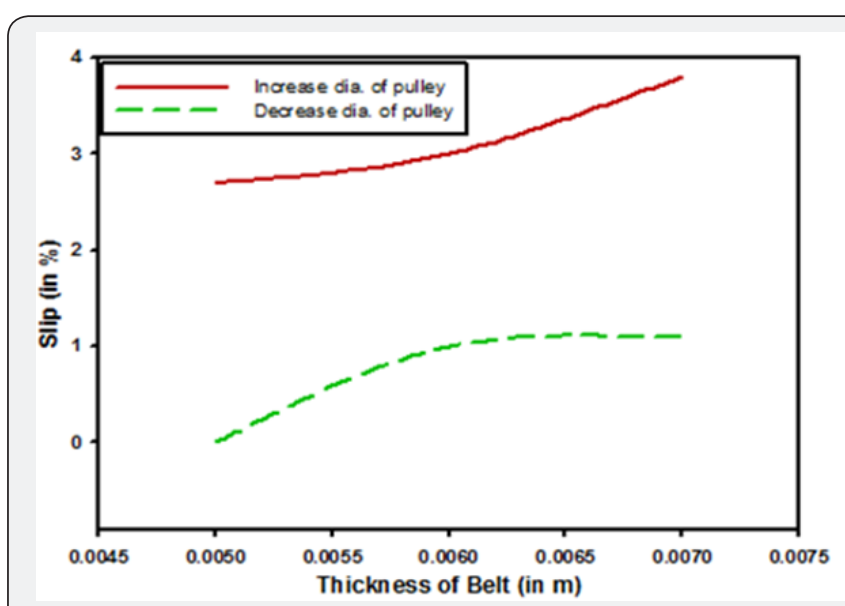

Figure 6: Thickness vs slip.

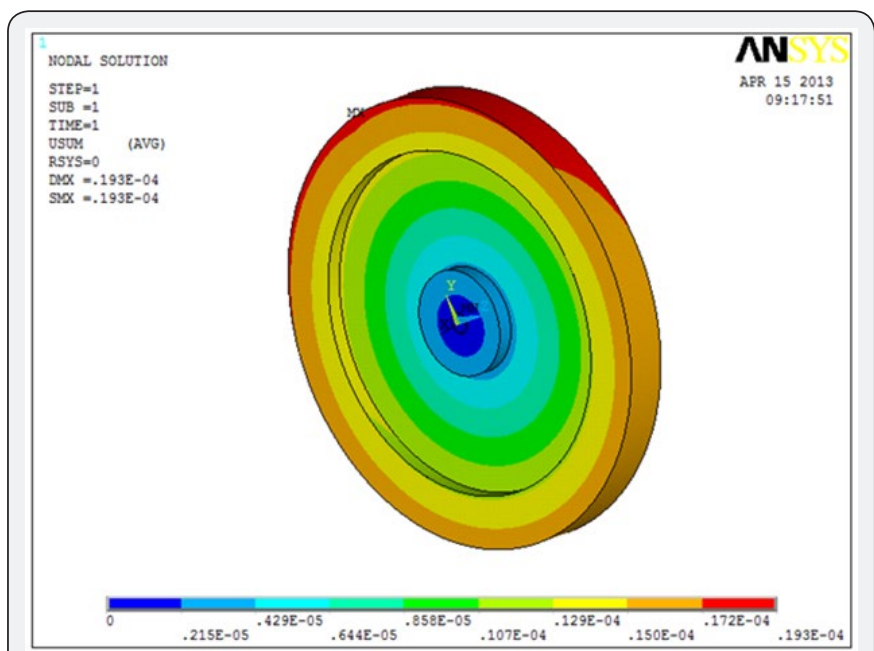

Figure 7: Total Deformation of Pulley.
Figure 5 showing when the coefficient of friction between the belt and pulley has increase then the value of tension (slack side \& tight side) will decreases. But both line follow same pattern. And also the 0.2 to 0.3 coefficient of friction will better value between belt and pulley.

Figure 6 showing when the thickness of belt increases also with increase of pulley diameter than the slip of belt increases. But, when the thickness of belt increases also with decrease of pulley diameter than the slip of belt decreases.

Figure 7 showing pulley simulation of piston-press machine, this simulation shows the total deformation of pulley. In this figure value of maximum deformation is $0.193 \mathrm{E}-04$.

Figure 8 showing that the von-Mises stress and shear stress on the pulley periphery through simulation.
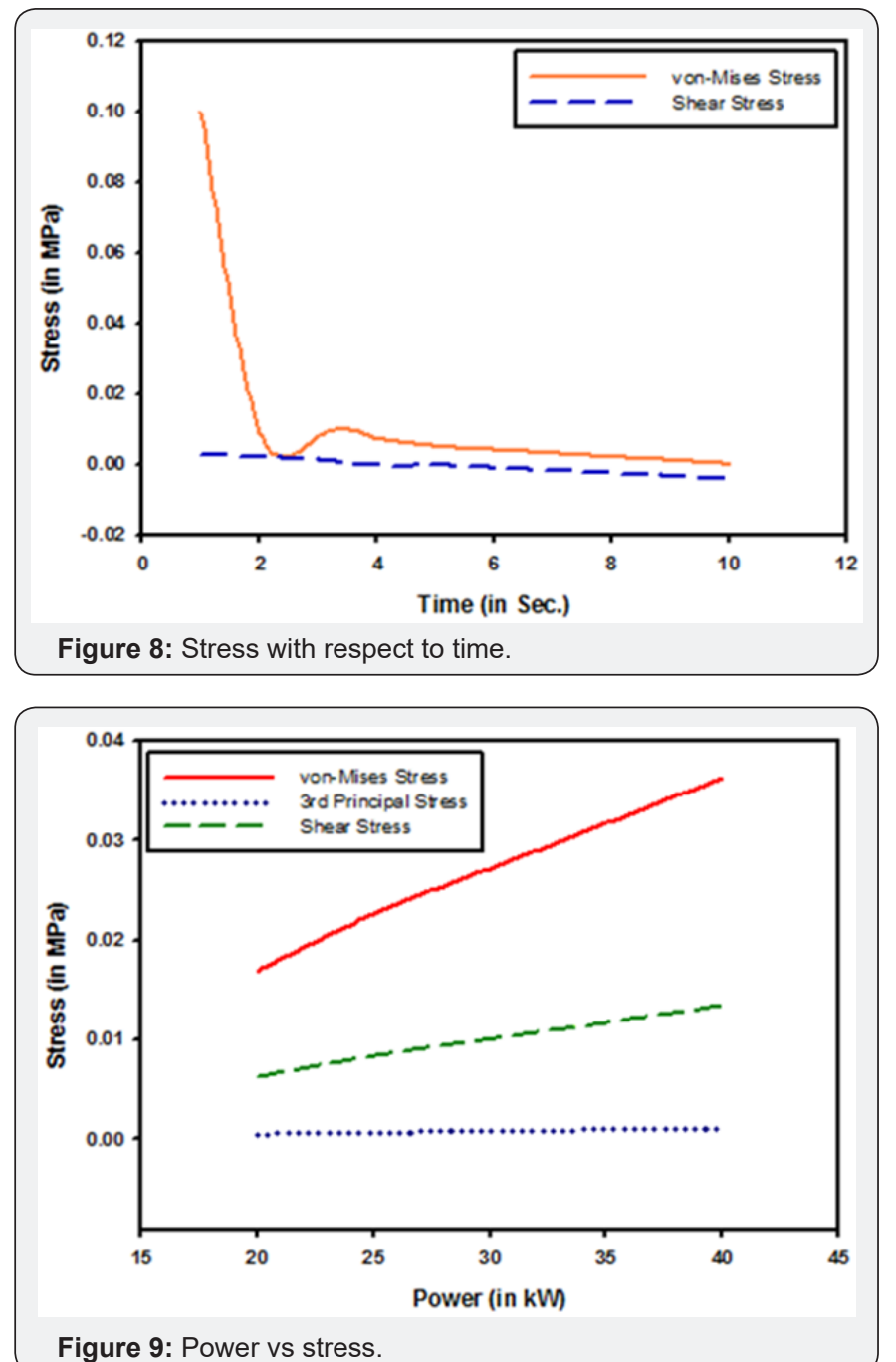

Figure 9 showing simulation results. In this graph of belt tension has analysed in terms of power. When the belt tight side tension has increased than the value of stresses (von-Mises stress, principal stress, shear stress) have follow same pattern, but the stress will also increasing. 


\section{Conclusion}

a) Coefficient of friction has play major role in tensions on belt.

b) Change of belt thickness decrease as well as increase the slip of belt. Also the change in diameter of pulley affects the slip of belt.

c) The simulation is easily finding the stress on pulley that occurs due to belt tension.

\section{References}

1. Mangesh V Wasekar, Baxi RN (2013) Failure analysis of collar of Biomass Briquetting Machine: A Review. International Journal of Engineering Research and Applications 3(2): 437-439.
2. Kapil A Pakhare, Baxi RN (2012) Failure analysis of taper die of biomass briquetting machine: a review. IJESS 2(10): 39-50.

3. Deepak Singathia, Aggarwal ML (2012) Finite Element Modeling for Replacement of C.I. Pulley with Suitable Material. International Journal of Modern Engineering Research 2(5): 3028-3031.

4. Deniz Yilmaz, Kürșat Çelik H, Ibrahim Akinci (2009) Finite element analysis of a failure in rear-mounted mower pulley. Journal of Food, Agriculture \& Environment 7(3): 865-868.

5. Shrikant A Thote, Sonpimple MK, Mehta GD (2013) An Approach to Find the Stresses Induced In a Flat Belt during Half Rotation of a Driving Pulley. International Journal of Innovative Technology and Exploring Engineering 2(3)

\section{Your next submission with Juniper Publishers will reach you the below assets}

- Quality Editorial service

- Swift Peer Review

- Reprints availability

- E-prints Service

- Manuscript Podcast for convenient understanding

- Global attainment for your research

- Manuscript accessibility in different formats

( Pdf, E-pub, Full Text, Audio)

- Unceasing customer service

Track the below URL for one-step submission

https://juniperpublishers.com/online-submission.php 